\title{
EMPLOYMENT GROWTH IN THE SERVICE SECTOR 1981-1991
}

\author{
Paul Callister \\ Economic and Social Research
}

In 1988 the New Zealand Planning Councils National Sectoral Programme forecast that $77 \%$ of all new job in the period 1984 to 1992 would be in the service sector, and $85 \%$ in the 1992-1997 period. Across the whole of the service sector three industry groups - "wholesale and retail trade, restaurants and hotels", "finance and business services" and "community, social and personal services". were seen as the major contributors to this growth. ${ }^{1}$

In two related publications the Planning Council also noted the movement of Maori into service industries and there was optimism at the time about Maori increasing their presence in growth industries such as tourism. 23

Such forecasts raise questions of whether they would be in the higher skill, higher income parts of service sector such as banking or education or the lower skill, low income such as domestic services and cleaning. In two other Planning Council publications the view was expressed that the majority of the new jobs in the service industries could be high wage and high skill if we chose to pursue the goal of a "fully employed, high income society". 45

This paper examines these forecasts in relation to the actual growth in employment between 1986 and 1991, but to put the trends in a historical context includes 1981 data. It also raises questions about how appropriate the current industry grouping are in terms of analysing changing jobs and ultimately changing skill requirements.

\section{Some Definitional Issues}

Labour market analysts can look at change in employment by a number of variables, but industry and occupation are two of the key variables used. Occupational changes appear to potentially yield more important information on the type of activity being carried out as people have a good idea of, for example, what an accountant or a lawyer does. But for some occupations the work carried out in different industries can vary significantly. A labourer on the waterfront is likely to have very different characteristics from a labourer in the dairy industry in terms of skills used, work practices, income and contracts. Industry information can help set the occupational data in some context.

Industry based data is also important in terms of linking employment changes to changes in industry wide regulatory regimes, productivity changes by industrial grouping and data on export and imports.
For convenience both industry and occupational data is aggregated to see if trends are emerging. The way the data is aggregated however does have an impact on the conclusions being drawn about employment change.

Definitions of the service sector vary. In a 1991 article on services the Department of Statistics included "electricity, gas and water" and "building and construction" in the good producing sector, whereas the New Zealand Planning Council work these industry groups were placed in the service sector. Within the primary and manufacturing sectors there are also industries which seem to have characteristics similar to other service industries. These include "consultants" to agriculture, forestry and fishing, and the "publishing and printing industries".

There have been various attempts to regroup industries. Singlemman and Tienda regroup industries on the basis of extractive, transformative, distributive services, producer services, social services and personal services. This classification was used by Philip Morrison in his 1989 book on labour market adjustment. ${ }^{6}$ It utilises the existing two digit groupings of industries, but instead of bundling them in three sectors divides them into six sectors. A Japanese study suggested another grouping:

${ }^{\circ}$ Semi-housework services such as restaurants, cleaning and barber services.

'Development of industrial production, such as banks, transport and telecommunications

'Services for human activity or human ability such as education, social welfare, cultural activities, leisure and recreation. ${ }^{7}$

The Japanese regrouping represents a greater change as it pulls various industries out of the existing two digit groups and regroups them. Both these classifications are based on what is produced by the industry group and who uses it. Equally a broad grouping could be on the basis on commonality between inputs such as skill requirements. In terms of the deskilling/upskilling debate it would be interesting trying to regroup industries on their requirements for certain types of skills such as numeracy or communication.

This regrouping in terms of common skills or perhaps activities is not just an academic exercise. The Government's Industry Skills training strategy is based around the setting up of Industry Training Organisations 
whoare supposed tocover industries with common features. Employee representative groups have also at times grouped themselves around industries, rather than the traditional occupational groupings, an example being FINSEC.

Each of these systems of broadly grouping industries has its own set of advantages and disadvantages, so for this study I have started out using the definition of service industries which places NZSIC industry groups 4-9 in one bundle. However as the analysis proceeds it is clear that the broad industry groups are far from homogeneous either in terms of their outputs, who they sell to and their inputs.

It is also worth noting that industry groups were revised in 1987.8 This caused a number of minor, and a couple of major re-groupings. The most significant adjustment was the inclusion of motor repairs, moved from "community, social and personal services" to reflect the reality that petrol retailers usually also run a repair garage. I have adjusted the 1986 and 1981 Census data accordingly but as my data was not at a five digit level was not able to isolate out "panel beaters and spray painters", "auto-electricians" and "other motor vehicle services". This means I have inflated the retail sector by about 9500 in all three censuses, and understated "community, social, and personal services" by an equal amount. Overall the changes mean that researchers need to be careful if relying on published data when making comparisons between censuses.

In this paper when analysing employment trends, unless otherwise stated, the total number of jobs are recorded, that is the sum of full-time and part-time positions. This is an intentional departure from Full Time Equivalents for two reasons. Firstly there is some debate over the correct ratio to use. ${ }^{9}$ Secondly, for the non-researcher, FTE's have little meaning.

Finally it is worth noting some other definitional issues regarding the data used in the analysis. Part-time work is the standard Department of Statistics definition of 1-29 hours per week, Maori includes all those who identify themselves by origin or descent. The industry data is by standard NZSIC breakdown, with "business and financial services", "wholesale and retail trade, restaurants and hotels", and "community, social and personal services" able to be broken down at a four digit level, with a three digit breakdown of the other service industries.

\section{Aggregate Trends in the Service Sector}

As with most other developed nations, in New Zealand there have been major shifts in employment this century from primary and manufacturing industries to service industries.

The growth of the service sector is the result of both long and short term factors. The long term factors common to New Zealand and other developed countries involve an ongoing transition from an industrial to a post-industrial society. These long term changes are well set out in a 1991
Figure 1.Change in the number employed in the service sector 1981-1991: gender, hours and ethnicity

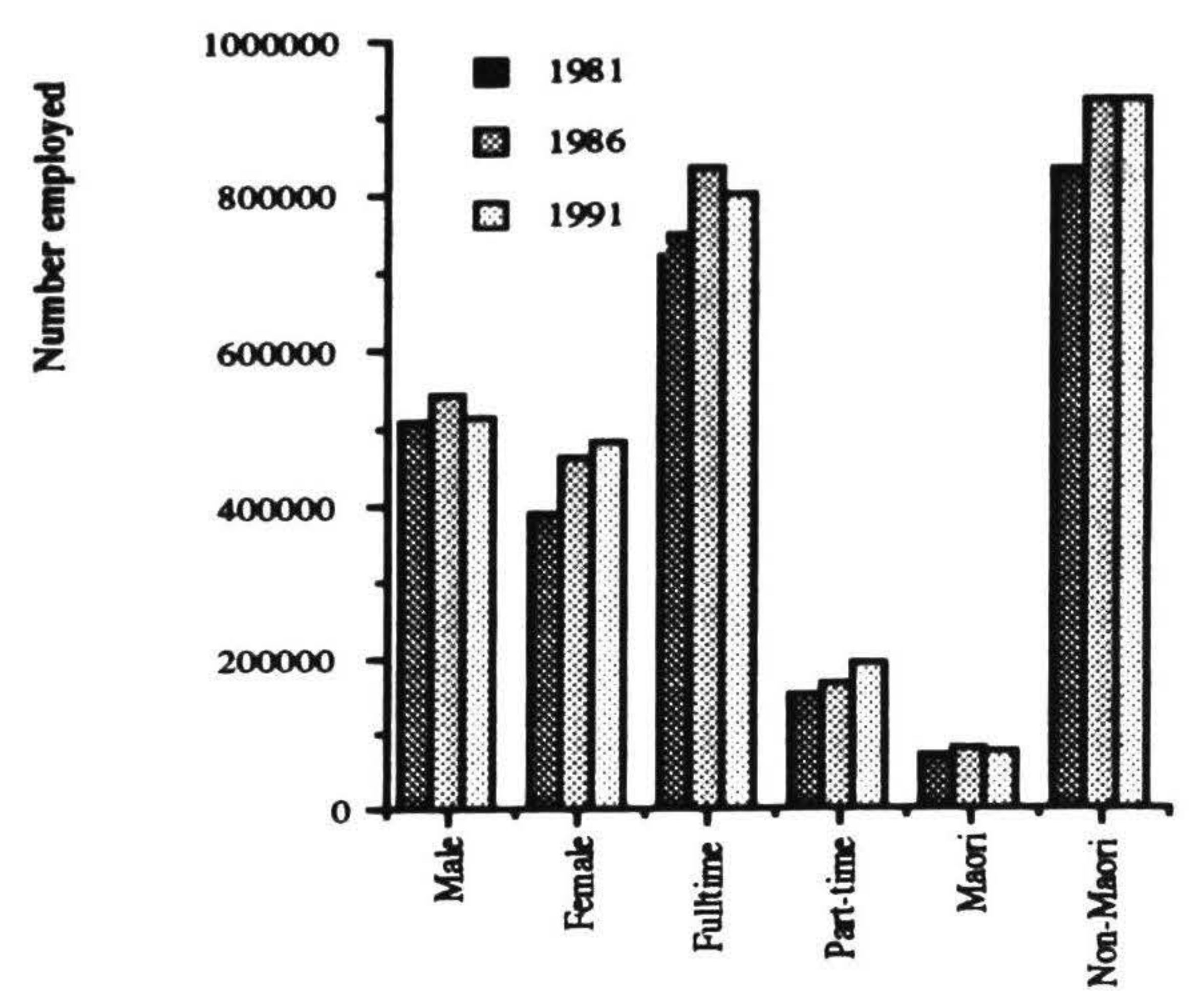

Source: Department of Statistics

article in the Department of Statistics Labour Force publication and by Britton. 1011 This paper however concentrates on the short term changes. De-regulation of industries, corporatisation and privatisation, government financial constraints and the rise and fall of general economic activity are major influences in the changes over the 1980s, but important social changes, such as people wanting to eat out more, also show up in the trends.

Labour market analysts will be familiar with the broad picture of job growth over the 1980s. Before getting into my more detailed analysis I will however look at some broad trends broken down in a variety of ways.

The growth in employment in services between 1981 and 1986, and the static state between 1986 and 1991 can be analysed in terms of gender, ethnicity and hours of work, Figure One. This shows a complex picture with men gaining ground then loosing it again, women increasing their presence throughout the whole period as did parttime workers, while full-time workers and Maori had gains in 1986 to drop back again by 1991 . The static state of nonMaori between 1986 and 1991 indicates that this group were more able to hold their jobs during restructuring but as subsequent analysis will show growth patterns by ethnicity are not homogeneous across the whole sector.

The changes in employment are more dramatic when shown at an industry level. The first panel of Figure Two shows the boom time between 1981 and 1986. In all major industrial categories there was growth in employment, with the strongest growth in the service area of "wholesale and retail trade, restaurants and hotels", followed by "business and financial services", then "construction" and "community, social and personal services".

The second panel of Figure Two shows the very strong reversal in trends in most categories of employment between 
Figure 2 Net change in employment by sector, 1981-1986 and 1986-1991, fulltime and part-time
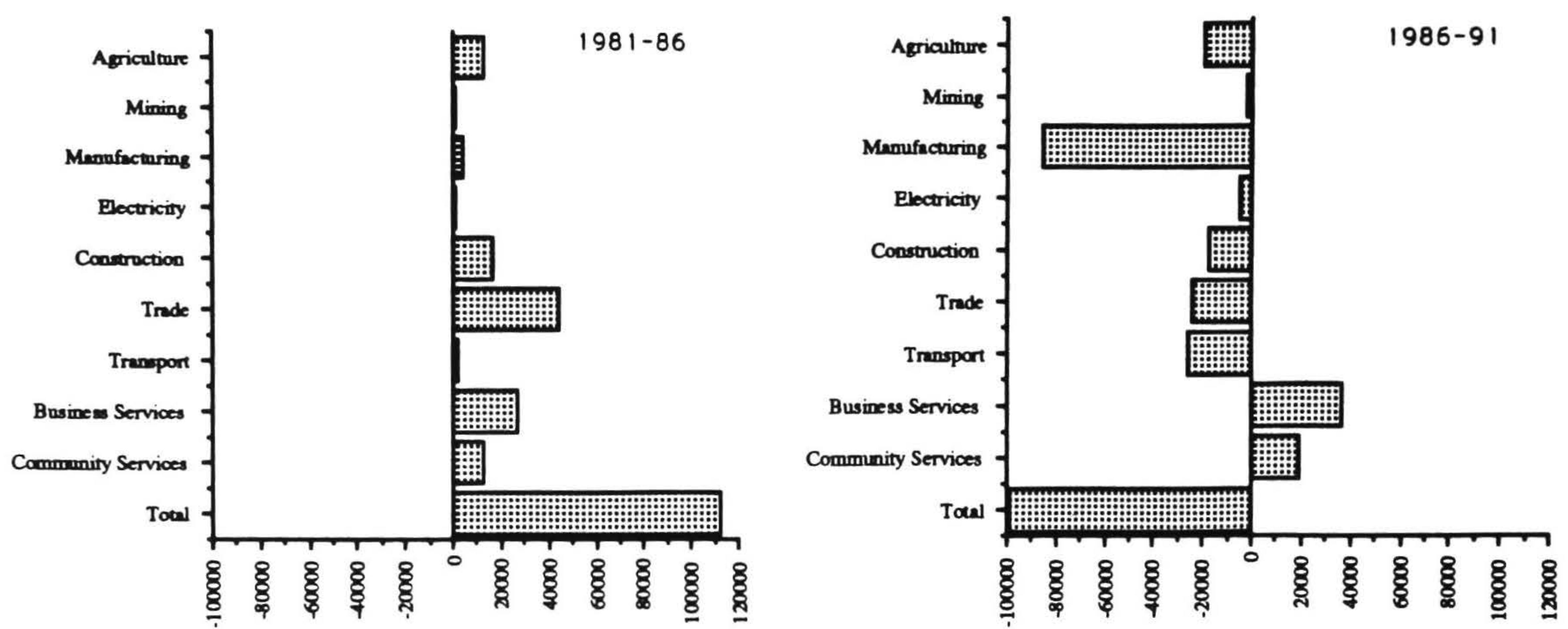

Figure 3. Net change in the number employed by sector, gender and hours worked, 1986-1991
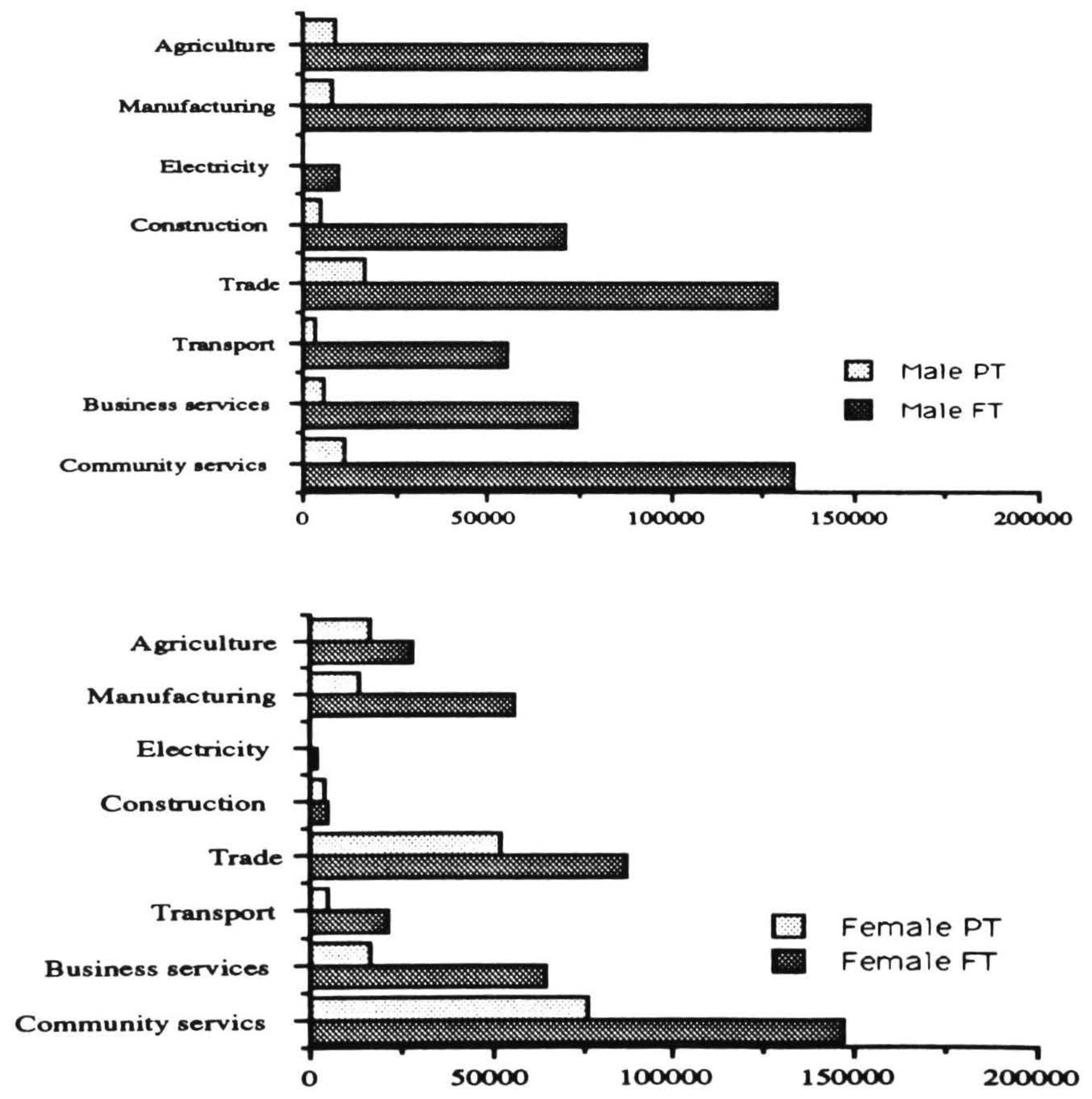

Source: Department of Statistics 
1986 and 1991 . The job losses were dominated by the very large decrease in manufacturing employment, but there continued to be reasonably strong growth in both "business and financial services" and "community, social and personal services".

These changes are also shown in Figure three, this time by gender and hours of work. While this pattern maybe familiar to most labour market analysts I have included it in order to illustrate the major problem of having so many industries bundled into the two service industries "wholesale and retail trade, restaurants and hotels" and "community, social and personal services". A surprising amount of labour market analysis is undertaken at a broad one digit level, particularly if other variables such as occupations are also being looked at, however the one digit level which over estimates the importance of industry groups such as "electricity, gas and water" and gives an insufficient breakdown of the large and growing industry groups.

\section{Trends}

In the service sector there are three one digit industry groups which provide a very small proportion of the employment, and a further three which provide the bulk of the employment. "Electricity, gas and water", "construction" and "transport, storage and communication". Not only are the groups different in size but their employment trends seem to be quite different.

\section{The "small" service sector employers}

"Electricity, gas and water", "Construction", "transport, storage and communication" all suffered large job losses in the latter part of the 1980s. These are service industries which had a relatively high concentration of Maori in 1986. ${ }^{12}$

In New Zealand Planning Council discussions with Iwi there was often the view put forward that in these type of industries Maori were disproportionately made redundant. The data lends some support to this view. In 1981 Maori formed $12.6 \%$ of the electricity workforce, but by 1991 this had dropped to $11.9 \%$. For construction in 1981 Maori represented $11.5 \%$ of this workforce, by 1991 it had dropped to $9 \%$. And in telecommunications and postal services Maori employees represented $11.6 \%$ of the workforce in 1981. This had dropped to $11.3 \%$ in 1991.

Maori not fared well in most of these industries. On the surface the restructuring of telecommunications may look like a simple downsizing with jobs more likely to be held onto by those with better education, and perhaps seniority, thus creating problems for Maori. But writers such as Zuboff ${ }^{13}$ suggest there has been a dramatic change in the type of work carried out in this type of industry. Up until the early 1980 s the jobs in telecommunications were probably more closely related to activities in primary and manufacturing sectors, with many physical jobs such as linesmen, and with many of these positions in rural situations. Now more the job is more likely to be in an office behind a computer analysing data. This is particularly the case with new comers into the industry such as Clear Communications. Without the large network to maintain they have more sales people than "technical" personnel. ${ }^{14}$ To get a good idea of restructuring of these industries need to go beyond even detailed occupational data on a focussed industry basis, into case studies on the actual type of work being carried out and the work arrangements. Enterprises are of course now doing such as activities through techniques such as skills audits and through re-examining organisational structures on a regular basis.

\section{The "Large" Service Sector Employers}

There are a wide range of factors influencing the grous th of this sector, and an initial breakdown into retall usuce and restaurants and hotels shows some significant dillere ra cs: see Table 1

The two industry areas "textiles, clothing and $1,1 \mathrm{n} \sim \mathrm{ncar}$ " and "furniture, soft-furnishing and floor covernng" are included in table five as examples of retailing which improved up to the sharemarket crash then decline d in the following recessionary period. This type of retaling has the potential to grow again quickly in employment terms should the domestic economy show strong growth. The "sports goods and camping" category is included to show there can be retailers going against the trend. Perhaps this is an example of the leisure society or people perhaps going down market in terms of holiday accommodation during a recession.

Overall retailing lost a significant number of jobs during the latter part of the 1980s an indicator of a weak domestic economy. Yet it is one of the few areas in the economy where Maori went against the trend, if only somewhat marginally. In 1981 Maori represented $4.8 \%$ of the workforce, by 1991 this had increased to $5.7 \%$. It will be interesting to see if Maori moves such as the purchase of DEKA will continue the growth of Maori employment in this industry group. It would be also interesting to know if the increase in Maori employment is in retailing with a strong connection to tourism or just in general retailing.

Two other areas are important in this overall sector group, eating out and accommodation. Takeaways have been isolated out to show how even in a recession the trend continues towards eating out and in particular a trend towards fast convenience food. Overall employment increased in eating and drinking establishments in the 1980s although post the sharemarket crash maybe the growth has been more in the lower end of the market. Certainly in places such as Wellington during the 1980s there has been the emergence of a new "cafe society".

In the "restaurant" industry there is a high level of parttime work by women, but there has also been growth in full-time work; Table 2. 
Table 1. Employment in selected areas of retail trade 1981-1991 Full-time and Part-time work

$\begin{array}{lrrr} & 1981 & 1986 & 1991 \\ \begin{array}{l}\text { Groceries and food } \\ \begin{array}{l}\text { Textiles, clothing, and } \\ \text { footwear }\end{array}\end{array} & 35,979 & 38,712 & 39,567 \\ \begin{array}{l}\text { Furniture, soft-furnishings } \\ \text { and floor coverings }\end{array} & 14,520 & 16,437 & 14,160 \\ \begin{array}{l}\text { Sports goods and camping } \\ \text { Total retail trade }\end{array} & 4,644 & 5,418 & 4,293 \\ & 1,170 & 1,560 & 1,653 \\ & 150,693 & 165,486 & 152,751\end{array}$

Source: Department of Statistics

Table 2. Employment in eating and drinking establishments 1981-1991 Full-time and Part-time work

$\begin{array}{lccc} & 1981 & 1986 & 1991 \\ \text { Takeaways } & 5,745 & 7,998 & 9,306 \\ \text { Total food and drink establishments } & 25,254 & \mathbf{3 4 , 2 3 3} & \mathbf{3 6 , 5 5 2}\end{array}$

Source: Department of Statistics

Table 3. Employment in accommodation industries 1981-1991 Full-time and Part-time work

$\begin{array}{cccc} & 1981 & 1986 & 1991 \\ \text { Total accommodation } & 21,390 & 25,575 & 21,957\end{array}$

Source: Department of Statistics

Despite the overall growth, Maori employment actually declined between 1986 and 1991 from 3600 to 3237. The decline is also shown up in Maori as a percentage of the workforce which increased from $9.5 \%$ in 1981 to $10.5 \%$ in 1986 then dropped back to $8.9 \%$. This is a worrying trend given the key place eating and drinking establishments have in the tourism sector.

The data on accommodation is surprising given the strong growth in inward tourism; Table 3. Perhaps the explanation is in part that more New Zealanders are travelling overseas for holidays and also that the domestic recession has cut back on local travel.

Again Maori fared badly in this sector with numbers initially rising from 2733 in 1981 to 3177 in 1986, but dropping to 2361 in 1991 . This is below the 1981 figure. Maori as a proportion of the workforce also declined from $12.8 \%$ in 1981 to $12.4 \%$ in 1986 , then dropping further to $10.8 \%$ in 1991 . It may be a case of owner/operators who are more likely to be Pakeha shedding Maori labour during a recession. Again this is a worrying trend given the potential for tourism to create jobs, and the key place Maori should have in this growth.

The overall trends in retailing, eating and drinking establishments and accommodation point to the problems of lumping together industries at a one or even two digit level when looking at possible future employment growth. Most areas of retailing, but not all, seem to be closely linked to the level of overall economic activity so can be modelled in a relatively simple economic equation. The eating/drinking trend seems to be more linked to social change which is changing the historical equation. Putting these social trends into models represents an interesting challenge for forecasters and perhaps points to a need for more collaboration between economists and other social scientists.

\section{Community, social and personal services}

"Community, social and personal services" covers a wide range of industries (and occupations). A key feature of this sector is that many of its activities are government funded or "non-market". Some commentators argue that growth of the service sector as a whole "derives in a large part from state expenditure" but this view ignores growth of retailing and business services. ${ }^{15}$ However in "community, social and personal services" much of the growth can be directly linked to government spending. In areas such as education and health government is now trying to increase the level of private funding and the effect of this on the growth of the sector is open to debate. 
Apart from government activities there are a diverse range enterprises in this industry grouping which in many ways do not fit comfortably with each other. In the area of personal services it is difficult to see why repair shops, drycleaners, hairdressers and photographic studies should not be part of retail trade. These are to be found grouped with other retailers, plus eating houses, in any shopping complex. The output is similar, the group being serviced is the same and the skills utilised by the employees would be very similar. Already jewellers who make repairs and garages fixing vehicles have been moved across to retailing recognises that sales and repairs often go together.

Ownership also has an influence on whether an industry is in this industrial grouping. ACC and the New Zealand Employment Service are in this group, but if they were privatised they would be presumably be moved to the finance sector and business services. Even when activities are not government owned, but where the "market" is not the main mechanism for allocating good and services then industries tend to end up in this group. Doctors represent a peculiar mix of characteristics which could be also found in business services. Maybe at the end of the health reform process the business like Crown Heath Enterprises should be transferred to the business service industry group.

Then there are subtle differences which can place an industry in this area. If you are involved in collecting water and piping it into a household you work in the "electricity, gas and water" sector, if you pipe it out again and work in a sewerage treatment plant you are involved in community services. In dealing with either pure or impure water many of the activities and skills would be very similar.

The Singlemann and Tienda classification of industries divides "community, social and personal services" into two groups, that of social services and of personal services.

Figure 4. Employment growth in Community Services 1981-1991 by gender, hours and ethnicity

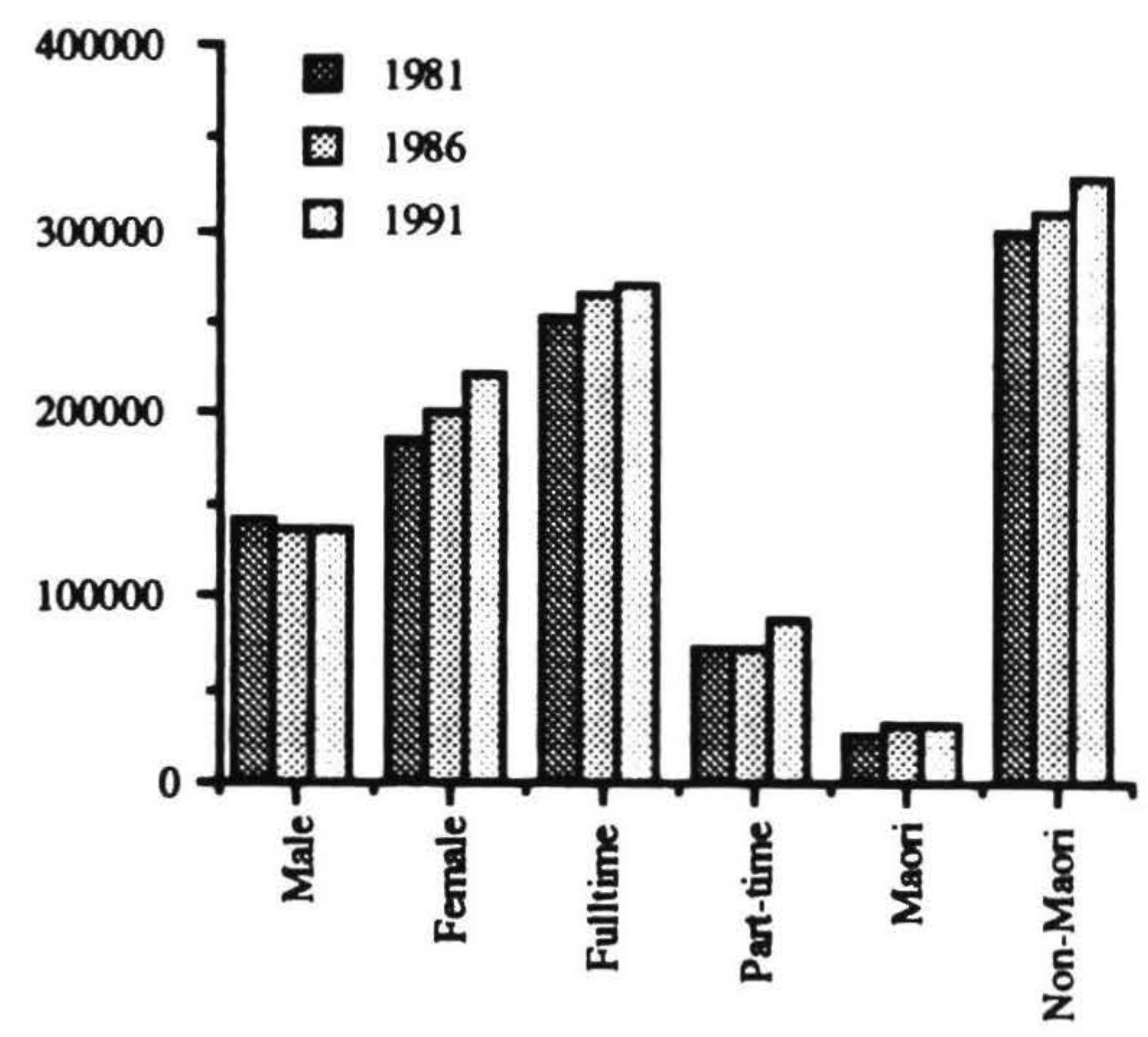

Source: Department of Statistics
But even this has it oddities. In this classification if you are going round cleaning carpets in domestic houses you are undertaking a social service, if you are a general house cleaner you are involved in personal services. Even when you get down to two digit classifications of industry, and then link these to occupation changes, the trends are still confused by having, for example in personal services, repair shops with their service and sales workers linked with the elementary occupations of cleaners.

However for the moment ignoring these classification issues there has been strong growth in "community, social and personal services" throughout the 1980s and HLFS data indicates this trend is continuing; Figure Four.

The upward trend in employment is not shared by all groups. It is significant that in this group of industries, which provide a significant proportion of New Zealand's total employment, and is an area which is growing and still forecast to grow, that men lost ground over the 1980s.

There is a mixture of positive and negative trends for Maori. Table four selects a number of industries which are influential in our society, plus two low wage, low status industries and shows Maori as a proportion of the workforce.

The increase in radio and television is most likely connected with the increase in Maori radio stations, but there may even have been some movement in mainstream media. In the category libraries and other cultural services the decline in Maori as a percentage is not due to declining Maori employment but that non-Maori employment grew at a faster rate. Maori form a significant, but falling proportion, of the cleaning industry, but the total number of jobs in this area is relatively small standing at 8574 in 1991.

Figure 5. Employment growth in Finance and Business services 1981-1991 by gender, hours and ethnicity

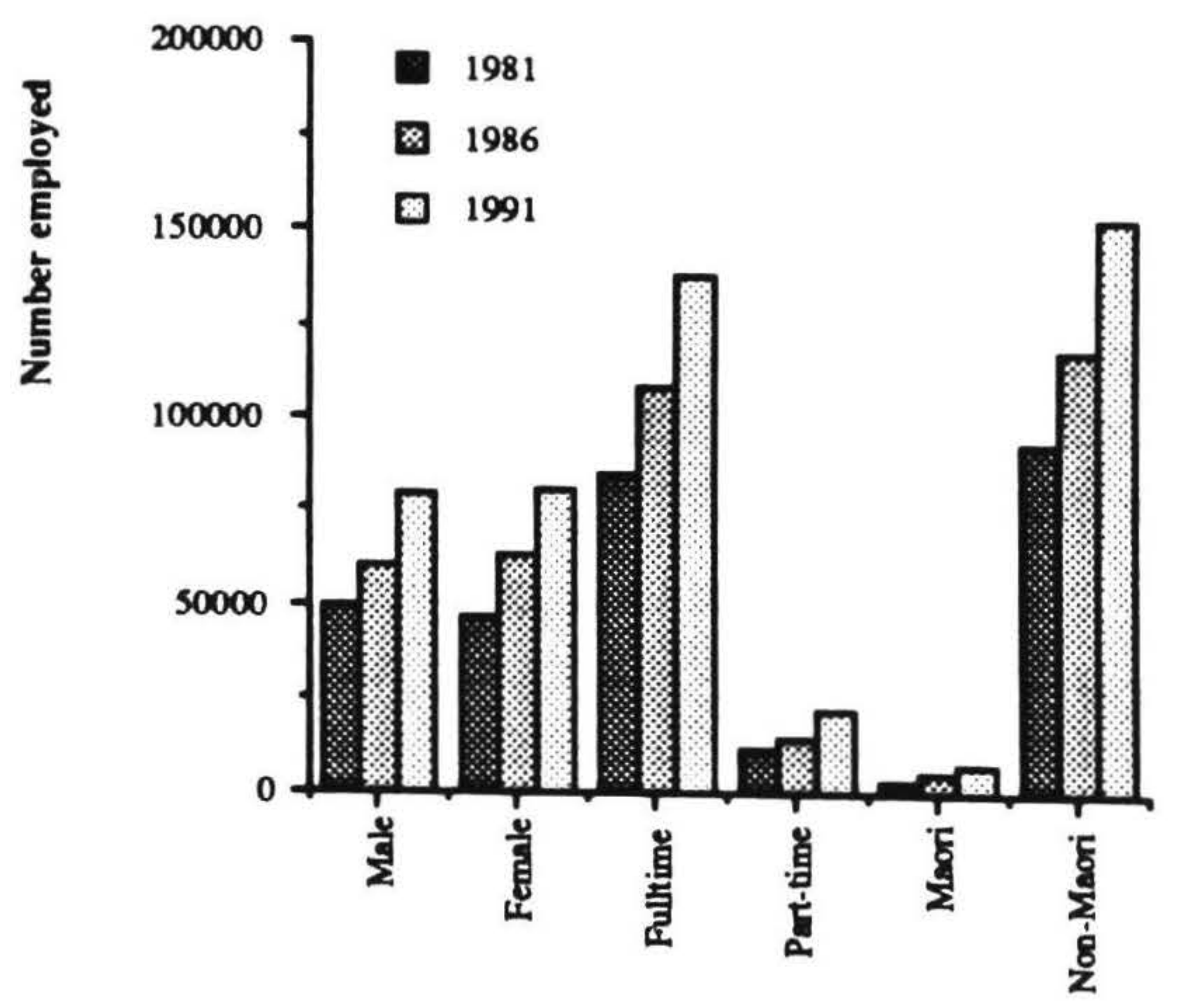

Source: Department of Statistics 


$\begin{array}{lrrr} & \mathbf{1 9 8 1} & \mathbf{1 9 8 6} & \mathbf{1 9 9 1} \\ \text { Central Government } & 11.6 & 11.2 & 13.0 \\ \text { Local Government } & 12.2 & 11.2 & 8.7 \\ \text { Education } & 5.5 & 7.1 & 8.4 \\ \text { Research Institutes } & 3.8 & 3.4 & 3.6 \\ \text { Medical and veterinary } & 6.9 & 6.4 & 6.1 \\ \text { Radio and television } & 3.7 & 4.4 & 7.0 \\ \text { Libraries \& other cultural services } & 5.9 & 8.9 & 7.7 \\ \text { Cleaning services } & 18.4 & 17.1 & 15.0 \\ \text { Private domestic services } & 7.4 & 6.6 & 7.6\end{array}$

Source: Department of Statistics

\section{Finance and business services}

I will conclude the sector breakdown by looking at "finance and business services". This sector grew strongly throughout the 1980s and HLFS data indicates that this growth is continuing. Some commentators view this as a "speculative" industry group potentially prone to a downturn post the sharemarket crash, but I feel that most of the growth is not the result of "wheeling and dealing" but reflects some deeper structural changes occurring in the economy. 16

Figure Five shows growth in jobs by gender, hours of work with also a Maori/non-Maori split. The chart shows there has been growth in each of these categories.

The restructuring of the finance industry has caused problems for those collecting data and ultimately those people wanting to analyse the trends. Comparisons between 1981 and 1991 are difficult at a detailed level but overall trends can be looked at. I have selected out a couple of minor categories and the major groups, Table 6 .

The fall-out from the sharemarket crash can be seen in the category "stocks and share broking". The growth in the finance sector reflects a number of changes in our economy. The dollar was floated creating a greater demand for foreign currency risk management services. In other areas of business risk has also been transferred from the government to private individuals also creating a new demand for financial services.

The growth in business services has also been very strong. As with "community, social and personal services" there are some positive trends for Maori in this sector. The following chart shows Maori employment in some key industries in the sector. Even in advertising services, where there has been a slight percentage decline, actual numbers have increased from 147 in 1981 to 273 in 1991.

\section{Conclusion}

The New Zealand Planning Council's National Sectoral Programme forecasts of continuing growth in the service sector in the latter part of the 1980 s were broadly correct , although somewhat askew on the detailed industry predictions. For Maori the employment predictions by the Planning Council were overly optimistic, although at a detailed industry level the pattern of growth or decline varies considerably. In traditional areas of employment such as construction Maori have lost ground, however in non-traditional areas, which are usually associated with higher skill requirements and ultimately higher incomes, such as education services, banking and accounting they have made small but significant gains. The lack of progress,

Table 5. Employment in selected ares of the finance industry Fulltime and Part-time work

$\begin{array}{lrrr} & 1981 & 1986 & 1991 \\ \text { Stocks and share broking } & \text { N/A } & 1,311 & 591 \\ \text { Mainstream banking } & \text { N/A } & 24,564 & 28,224 \\ \text { Building societies } & \text { N/A } & 1,374 & 304 \\ \text { Total Finance } & 30,291 & 37,668 & 40,221 \\ \text { Insurance and superannuation } & 14,640 & 14,454 & 15,525\end{array}$

Source: Department of Statistics 
Table 6. Maori employees as a percentage of total employees in selected areas of finance and business Fulltime and Part-time jobs

$\begin{array}{lcc} & 1981 & 1991 \\ \text { Banking } & 3.6 & 5.2 \\ \text { Legal services } & 2.4 & 3.0 \\ \text { Accounting } & 2.1 & 2.3 \\ \text { Advertising services } & 3.6 & 3.5 \\ \text { Total employment in all industries } & 9.3 & \mathbf{8 . 3}\end{array}$

Source: Department of Statistics

in employment terms, in industries with links to tourism is of particular concern.

The census data shows that the service sector continued to grow in importance in terms of employment over the 1980s. In particular two areas "finance and business services" and "community, social and personal services" continued to generate new employment, going against the trend of job losses in all other sectors. A significant proportion of these new jobs involved full-time work, despite the overall economy wide trend of a move to parttime employment. It also appears that the bulk of the new jobs in these sectors have not been in traditionally low wage, low skill areas such as domestic work but have in fact been in relatively high income industries such as banking. Whether they are actually high income jobs is not answered by this research.

In the latter part of the 1980s there were significant job losses in the large employment area of "wholesale and retail trade, restaurants and hotels". However the data shows that the trends within the sector vary substantially with some trends linked to the recession, but others linked to more fundamental changes in lifestyle. In modelling exercises it is important to try and bring in these changing social trends rather they relying simply on past relationships of flows between industries and individuals. If growth in the domestic economy is sustained there is the potential to re-generate jobs in many areas of retailing which faced a decline post 1986.

Overall the trends in the service sector, in simple employment terms, have been positive for women and those wishing to work part-time, but have been negative for men in full-time work.

This industry analysis however raises issues about the both the NZSIC classification system, and attempts to regroup industries into seemingly homogeneouscollections such as "service industries". Clearly many of the industries vary considerably in terms of what they produce, who they sell it to, and the skills utilised in the production process. Even when attempts are made, such as by Philip Morrison, to link industries at a two digit level to two digit occupations, industries with quite different characteristics can be lumped together. ${ }^{17}$ The industry grouping causing particular problems is that of "community, social and personal

services" as it not only has a diverse range of industries within it, but it is also the largest employment group and provided a high proportion of the new jobs in the latter part of the 1980s. Already some industries have been moved across to retail trade post 1987 , but with changes of ownership and other restructuring occurring in this area it is likely more industries will eventually move out into other groupings. In the meantime however it would be worth examining whether this industry group can be broken down into two or more one digit groupings. In the longer term other, perhaps more radical , ways of re-grouping industries should be considered

\section{Future Research}

Despite the effort going into labour market research little is still known about the changing pattern of work on an historical basis, and even less can be said about expected patterns of employment. The on-going restructuring of the economy is however creating problems with the traditional tools for measuring changes, such as the current classification and grouping of industries, and how "skills" are measured through qualifications. The Department of Statistics Labour Market Review identified many of these problems, and clearly considerable thought needs to go into redeveloping suitable tools for analysis.

The Labour Market Review also identified the potential to gain new insights into labour market issues through the use of a data laboratory. Currently many projects are small and carried out in isolation. They often deal with data sets with a relatively small number of variables, partly due to the cost and availability of the data, so the real complexities and inter-relationships in the labour market go unexplored. The availability of the data laboratory will hopefully allow researchers to design much more complex research programmes, with the additional, and important, ability to throw up and question a range of hypotheses as the project proceeds.

In examining the more narrow area of the skills debate even developing complex models of the labour market using official statistic has its limitations. Case studies are needed to give a better understanding of changes within industry because along with actual job changes we need to know about organisational structures, whether industries are part of an "internationalised" network, and whether 
they are targeting a high quality segment of the market. This first of all requires a better definition of skill. Skills are being defined in documents such as the draft curriculum publication, but we do not know much about the use of the skills such as numeracy of communication within various industries and occupations. ${ }^{18}$ To undertake such work on skill and linking it to labour market analysis, and finally back to the providers and users of education services will require considerable collaboration amongst researchers from varying disciplines. The Labour, Employment and Work forum assists this process, but perhaps in the new "information" age new techniques of regular communication between researchers, such as E-Mail, needs to be more fully developed.

\section{Notes}

${ }^{1}$ National Sectoral Programme. Prospects: Economic and Sectoral Trends to 1997. New Zealand Planning Council, 1988.

${ }^{2}$ Callister, Paul. Implications for Maori Development: Economic and Sectoral Trends to 1997. New Zealand Planning Council, 1989.

${ }^{3}$ Haines, Lesley. Work Today: Employment Trends to 1989. New Zealand Planning Council, 1989.

${ }^{4}$ Rose, Dennis. The Fully Employed High Income Society. New Zealand Planning Council, 1990.

5 Callister, Paul. Tomorrow's Skills. New Zealand Planning Council, 1990

${ }^{6}$ Morrison, Philip, S. Labour Adjustment in Metropolitan Regions. Institute of Policy Studies, 1989

${ }^{7}$ Uno, Kimio. Measurement of Services in an Input Output Framework, Amsterdam, 1989

${ }^{8}$ New Zealand Standard Industrial Classification, Department of Statistics, 1987.

${ }^{9}$ Rose, Dennis. A Review of Labour Market Statistics. Department of Statistics, October 1992.

${ }^{10}$ Krishnan, Vasantha Employment in the Service Sector New Zealand Labour Force - June 1991 Quarter, Department of Statistics.

${ }^{11}$ Britton, S. Understanding the 'Service Economy': A Preliminary Review of Theory. Occasional Publication 23, University of Auckland, 1989.

12 As in two

${ }^{13}$ Zuboff, Shoshana. In the Age of the Smart Machine Basic Book Inc, New York, 1988

${ }^{14}$ Personal communication with Telecom employees, Tall Poppies Seminar, March 1992

${ }^{15}$ Miles, I.D., and Gershuny, J.I. Towards a New Social Economics. (to be filled in)

16 Same as 10

${ }^{17}$ Same as 6

18 The National Curriculum of New Zealand Draft discussion document, Ministry of Education, 1991.

\section{References}

Bascand, A and Clements, R. 1989 The effects of restructuring on employment: 1985-1989 Reserve Bank Bulletin 52(2).

Callister,P.D. 1991 Expanding our horizons-New Zealand in the global economy. New Zealand Planning Council.

Callister, P.D. 1990 Tomorrow's Skills New Zealand Planning Council

Economic Monitoring Group 1989 The economy in transition - Restructuring to 1989. New Zealand Planning Council.

Morrison, P.S. 1991 Job Loss and unemployment in New Zealand during the 1980s Working Paper No 8 Department of Geography, Victoria University of Wellington.

Perry, M. 1989 Auckland's Producer Service Industry Patterns of change. Department of Geography, University of Auckland.

Philpott, B 1990 A consistent data base of sectoral employment 1959-1990 Research Project on Economic Planning Internal Paper 223 Victoria University of Wellington. 